\title{
SYMEON I WIELKI, WŁADCA BUŁGARII W PRZEKAZIE LEONA DIAKONA (HISTORIA, VII, 7)
}

\author{
MiROSŁAW J. LESZKA
}

\begin{abstract}
Simeon I the Great, the ruler of Bulgaria in the account of Leo the Deacon (Historia, VII, 7) Simeon in the account of Leo the Deacon (Historia, VII, 7) is an unambiguously negative figure. A bold barbarian who dared not only to raid Byzantine territories, but also to demand that the Romans proclaim him a ruler. Even his victory at the Battle of Anchialos (917) was not the result of his military prowess, but a tear in the Byzantine camp. It should be clearly emphasized that he was not the hero of the aforementioned passage of Leo the Deacon's work, but Leo Phokas. The Bulgarian ruler was only a convenient tool in the hands of the Byzantine author for the purpose of showing a rather trivial truth that disagreement in one's own camp and the desire for power lead to misfortunes, both for the individuals and for the nation.

STRESZCZENIE. Symeon w przekazie Leona Diakona (Historia, VII, 7) to postać jednoznacznie negatywna. Butny barbarzyńca, który ośmielił się nie tylko najeżdżać na bizantyńskie terytorium, ale i żądać, by Romajowie proklamowali go swoim władcą. Nawet zwycięstwo w bitwie pod Anchialos (917) nie było owocem jego wojskowego kunsztu, a skutkiem rozdarcia w obozie bizantyńskim. Bułgarski władca był w rękach bizantyńskiego autora jedynie wygodnym narzędziem do realizacji celu ukazania dość banalnej prawdy, że niezgoda we własnym obozie i żądza władzy prowadzą do nieszczęść tak w wymiarze osobistym, jak i całego państwa.
\end{abstract}

Author: Mirosław J. Leszka, Uniwersytet Łódzki, Wydział Filozoficzno-Historyczny, Instytut Historii, Katedra Historii Bizancjum, ul. Aleksandra Kamińskiego 27a, 90-219 Łódź, mirleszka@poczta.onet.pl ORCID iD: https://orcid.org/0000-0003-2643-4520

Keywords: medieval Bulgaria, Symeon I the Great, Leo of Deacon, the battle of Anchialos 917

Słowa kluczowe: średniowieczna Bułgaria, Symeon I Wielki, Leon Diakon, bitwa pod Anchialos 917

Balcanica Posnaniensia. Acta et studia, XXVI, Poznań 2019, Wydawnictwo Instytutu Historii UAM, pp. 33-41, ISBN 978-83-66355-32-3, ISSN 0239-4278. Polish text with summaries in English and Polish.

doi.org/10.14746/bp.2019.26.2

Leon Diakon ${ }^{1}$ przyszedł na świat najprawdopodobniej koło 950 r. w Kaloe w Azji Mniejszej, odebrał gruntowne wykształcenie w Konstantynopolu, gdzie rozpoczął duchowną karierę jako diakon w otoczeniu stołecznego patriarchy. Kontynuował ją póź-

${ }^{1} \mathrm{Na}$ temat życia i twórczości Leona Diakona patrz N. Panagiotakes, Leon ho Diakonos. A: Ta Bibliografika, B: Cheirografa kai eksdosis, Athenai 1965; S.A. Ivanov, Polemičeskaja napravlennost "Istorii”" Lva Diakona, „Vizantijskij Vremennik” 1982, t. 43, s. 74-80; O. Jurewicz, Historia literatury bizantyńskiej, Wrocław 1982, s. 181-182; M.J. Sjuzjumov, Lev Diakon i jego vremia, w: Lev Diakon, Istorija, perev. 
niej na cesarskim dworze. W 896 r. uczestniczył w wyprawie Bazylego II przeciwko Bułgarom. Zakończyła się ona kompletnym niepowodzeniem strony bizantyńskiej w bitwie w Bramie Trajana. Leon, podobnie zresztą jak i sam cesarz, ledwie uniknęli niewoli, a może nawet śmierci ${ }^{2}$. To wydarzenie musiało z pewnością wpłynąć na sposób widzenia przez historyka Bułgarów i to nie tylko mu współczesnych.

Leon Diakon w swoim dziele zatytułowanym Historia, a przedstawiającym dzieje cesarstwa między 959 a 976 r. wykazuje się sporym zainteresowaniem Bułgarami. Mimo tego, że jego praca nie obejmuje chronologicznie początków państwa bułgarskiego, to podaje on informacje o pochodzeniu Bułgarów i ich osiedleniu się nad Dunajem. Przedstawia dwie wersje tego wydarzenia. Zostały one już dawno przeanalizowane przez uczonych ${ }^{3}$ i nie ma potrzeby się nimi bliżej zajmować, ale warto zwrócić uwagę na to, że w obu wersjach Leon podkreśla fakt, że Myzowie (Bułgarzy) zajęli tereny należące do Romajów. W pierwszej stać się to miało przemocą, w drugiej zaś za zgodą cesarza Justyniana II w nagrodę za pomoc udzieloną mu w odzy-

M.M. Kopylenko, kommentarii M.J. Sjuzjumov. S.A. Ivanov, Moskva 1988, s. 137-165; J.N. Ljubarskij, Zamečanija ob obrazach i chudożestvennoj prirode „Istorii” Lva Diakona, w: idem, Vizantijskije istoriki i pisateli (sbornik statiej), Sankt-Peterburg 1999, s. 149-160; A. Karpozilos, Bydzantinoi istorikoi kai chronografoi 8-10os aiones, t. 2, Athenai 2002, s. 475-525; The History of Leo the Deacon. Byzantine Military Expansion in the Tenth Century, introd., transl., annot. A-M. Talbot, D. F. Sulivan, with assistance G. T. Dennis, S. McGrath, Washington 2006, s. 9-52; A. Kazhdan, History of Byzantine Literature (8501000), ed. Ch. Angelidi, Athens 2006, s. 278-286; L. Neville, Guide to Byzantine Writing, Cambridge 2018, s. 124-127. Edycja źródła - Leonis Diaconi Caloensis Historiae, rec. C.B. Hase, Bonnae 1828 (dalej: Leon Diakon). Część badaczy uważa, że Leon napisał swoją Historię w niedługi czas po $986 \mathrm{r}$. (np. M.J. Sjuzjumov, Lev..., s. 149). Bez względu na to, w jakim czasie po kampanii roku 986 Leon Diakon rozpoczął pracę nad swoim dziełem, to pewne jest, że pamięć o tym dramatycznym wydarzeniu była w nim ciągle żywa. Do końca pisania Historii Bizantyńczycy, jak można sądzić, nie osiągnęli w wojnie z Samuelem, takich sukcesów, które zmyłyby hańbę klęski w Bramie Trajana (pierwszy poważniejszy sukces bizantyński to bitwa nad rzeką Sperchejos w 997 r.) W tym kontekście prace nad Historia mogłyby zostać zakończone zarówno przed 991 r. (jak sądzi M. J. Sjuzjumov, Lev..., s. 149-150), jak i po roku 995, jak chce np. C. Holmes (Political Elites in the Reign of Basil II, w: Byzantium in the Year 1000, ed. P. Magdalino, Leiden 2003, s. 38, przyp. 8). Szerzej na temat zmagań Bazylego II z Bułgarami pisali, m.in. S. Pirivatrić, Samuilova država. Obim i karakter, Beograd 1997, s. 73-132; C. Holmes, Basil II and Governance of Empire (976-1025), Oxford 2005, s. 487-502; P. M. Strässle, Krieg und Kriegführung in Byzanz. Die Kriege Kaiser Basileios' II. gegen die Bulgarien 976-1019, Köln-Weimar-Wien 2006; T. Tomov, Ključ 1014, Sofija 2014; M.P. Panov, The Blinded State. Historiographic Debates about Samuel Cometopoulos and His State $\left(10^{\text {th }}-11^{\text {th }}\right)$, Leiden-Boston 2019.

${ }^{2}$ Opis wyprawy Bazylego II przeciw Bułgarom - Leon Diakon, X, 8. O swoich przeżyciach Leon tak pisał: I niewiele brakowało, a osłabłyby moje kroki i padłbym ofiara miecza scytyjskiego, gdyby mnie z tego niebezpieczeństwa nie wyprowadziła Boża opatrzność; ona sprawiła, że szybko na koniu pomknatem, zanim droge pełna wąwozów zajęli wrogowie, pokonatem ją i pędem wydostałem się na szczyt (tłum. A. Brzóstkowska - Testimonia najdawniejszych dziejów Słowian, seria grecka, zeszyt 5: Pisarze z X wie$k u$, przekł., oprac. A. Brzóstkowska, Warszawa 2009, s. 157). Leon w passusie, poświęconym tej wyprawie jednoznacznie oceniał Bułgarów jako zuchwałych, srogich i krwiożerczych.

3 Szerzej na ten stosunku Leona do Bułgarów i sposobu w jaki ich ukazywał - N.P. Blagoev, Kritičen pogled vărhu izvestijata na Lăv Djakon za bălgarite, „Makedonski Pregled” 1930, t. 6, nr 1, s. 25-48; 2, s. 23-40; P. Angelov, Bălgarija i bălgarite v predstavite na vizantijcite (VII-XIV vek), Sofia 1999, s. 99100 . 
skaniu tronu. Przy okazji Leon zwraca uwagę na wojowniczość Bułgarów, atakowanie przez nich bizantyńskich terenów i podkreśla, że jedynie trzem bazyleusom udało się ich pokonać na własnej ziemi. Byli to Konstantyn Kopronim, Konstantyn VI i Jan Tzymiskes ${ }^{4}$.

Swój emocjonalny i niechętny, o ile nie wrogi Bułgarom stosunek Leon Diakon wyraził, jak sądzę, w słowach wypowiedzianych rzekomo przez cesarza Nikefora II Fokasa do posłów cara bułgarskiego Piotra, którzy zjawili się na bizantyńskim dworze z misją przypomnienia Bizantyńczykom o niezapłaconym trybucie ${ }^{5}$. Cesarz miał określić Bułgarów mianem narodu scytyjskiego, nędznego i pod każdym względem podłego, a samego cara Piotra nazwać archontem gryzącym skórę i w skórę zwierzęcą odzianego. Piotrowi Nicefor miał poradzić, by on „będąc od przodków po trzykroć niewolnikiem (...) nauczył się traktować Romajów, jak panów"6. Jasno widać, że Leon eksponuje tu poczucie cywilizacyjnej wyższości Bizantyńczyków nad Bułgarami, co nie oznacza, że nie dostrzegał elementu łączącego Bułgarów i Bizantyńczyków, a mianowicie wiary. Leon w innym passusie swojej i wyraźnie pisze, że „Myzowie niezaprzeczalnie wyznają wiarę Chrystusową" ". Znamienne, że zwrócił na to uwagę w kontekście konfliktu Bizancjum z pogańskimi Rusami. Można z tego wyciągnąć wniosek, że wspólna wiara może być elementem jednoczącym w obliczu innowierców, ale nie stanowi gwarancji pokojowych stosunków między obu chrześcijańskimi państwami.

Interesująca mnie w tym artykule postać Symeona I Wielkiego ${ }^{8}$ pojawiła się w dziele Leona Diakona w związku z bitwą pod Anchialos stoczoną przez Bułgarów i Bizantyńczyków w sierpniu roku $917^{9}$. Wydarzenie to, podobnie jak rozważania o pojawieniu się Bułgarów na bizantyńskich ziemiach, znalazło się w Historii, nie

\footnotetext{
${ }^{4}$ Leon Diakon, VI, 8-9.

${ }^{5} \mathrm{Na}$ temat tego wydarzenia ostatnio - Z.A. Brzozowska, M.J. Leszka, K. Marinow, Piotr I Święty, car bułgarski (ok. 912-969), Maria Lekapena, caryca bulgarska (ok. 912-?963), Kraków 2018, s. 132-134.

${ }^{6}$ Leon Diakon, IV, 5 (tłum. A. Brzóstkowska - Testimonia 5, s. 105).

${ }^{7}$ Leon Diakon, V, 3 (ttum. A. Brzóstkowska-Testimonia 5, s. 111).

${ }^{8} \mathrm{Na}$ temat Symeona literatura jest przeogromna, $\mathrm{z}$ tego względu podaję jedynie kilka najnowszych pozycji, w których Czytelnik znajdzie odwołania do dalszych prac: M.J. Leszka, Symeon I Wielki a Bizancjum. Z dziejów stosunków butgarsko-bizantyńskich w latach 893-927, Łódź 2013; Bălgarskijat zlaten vek. Sbornik w čest na car Simeon Veliki (893-927), red. V. Gjuzelev, I.G. Iliev, K. Nenov, Plovdiv 2015; Simeonova Bălgarija v istorijata na evropejskija jugoiztok: 1100 godini ot bitkata pri Aheloj, red. A. Nikolov, N Kănev, t. 1-2, Sofija 2018.

${ }^{9} \mathrm{Na}$ temat stanu stosunków bułgarsko-bizantyńskich w dobie bitwy pod Anchialos, jak i samej bitwy patrz m.in.: V. Zlatarski, Istorija na Bălgarskata dăržava prez srednite vekove, t. I.2, Sofia 1927, s. 380388; D. Angelov, S. Kašev, B. Čolpanov, Bălgarska voenna istorija ot antičnostta do vtorata četvărt na Xv., Sofia 1983, s. 268-272; I. Božilov, Car Simeon Veliki (893-927); zlatnijat vek na Srednovekovna Bălgarija, Sofia 1983, s. 121-126; idem, V. Gjuzelev, Istorija na srednovekovna Bălgarija VII - XIV vek, Sofia 1999, s. 255-256; M.J. Leszka, Symeon I Wielki...., s. 159-186; Simeonova Bălgarija...
} 
ze względu na to, że rozegrało się w okresie, który ona obejmuje (959-976). Leon przywołał je z innych powodów. Uznał, że znakomicie nadaje się jako materiał poglądowy w kontekście jego rozważań dotyczących nazywania miejsc, w których doszło do jakiegoś tragicznego wydarzenia ${ }^{10}$. Bitwa pod Anchialos została wpisana w losy Leona Fokasa ${ }^{11}$, który za próbę uzurpacji został ukarany oślepieniem. Miejsce, w którym do tego doszło nazwane zostało Oeleon/Goleon ${ }^{12}$. Aby dojść do tragicznego finału losów Leona historyk opowiada czytelnikowi o jego udziale w zmaganiach Bizantyńczyków z Bułgarami w 917 roku. Dobór tego przykładu, o czym pisałem już przy innej okazji, nie był przypadkowy ${ }^{13}$. Położenie nacisku na opis bitwy pod Anchialos, której losy i znaczenie mógł historyk porównać do bitwy w Bramie Trajana, i to nie tylko ze względu na jej niekorzystny dla Bizantyńczyków finał, ale i fakt, że jedna i druga przyniosły w konsekwencji wewnętrzne niepokoje w cesarstwie bizantyńskim - po Anchialos bunt Leona Fokasa, a po bitwie w Bramie Trajana uzurpacje Bardasa Sklerosa i Bardasa Fokasa ${ }^{14}$. Jeśli dodamy do tego emocjonalny stosunek Leona Diakona do Bułgarów, to wybór przykładu Leona Fokasa z wplecionym wątkiem Anchialos i Symeona staje się całkowicie oczywisty. Warto podkreślić, iż opowieść o tym wydarzeniu nadawała się znakomicie do celów, jakby można rzec dydaktycznych, które realizował historyk ${ }^{15}$.

Jak ukazuje Leon Diakon Symeona w kampanii roku 917? Historyk przedstawił najpierw przyczyny konfliktu bizantyńsko-bułgarskiego ${ }^{16}$. Wskazał, że po śmierci cesarza Aleksandra władza przeszła w ręce Konstantyna VII, małoletniego syna Leona VI i jego matki Zoe. Słabość ich rządów wykorzystał Symeon, archegos Myzów, którego dziejopis określa mianem męża odważnego i zuchwałego w walce ${ }^{17}$. Przytoczone

${ }^{10}$ Leon Diakon, VII, 6.

${ }^{11}$ Leon urodził się ok. 875-880 r. Był synem Nicefora Fokasa Starszego. Na jego temat patrz I. Durić, Porodica Foca, Zbornik Radova Vizantološkog Instituta 17, 1976, s. 240-246; J.-C. Cheynet, Les Phocas, w: Le Traité sur la guérilla (De velitatione) de l'empereur Nicephore Phocas (963-969), ed. G. Dagron, H. Mihaescu, Paris 1986, s. 296-297.

12 Leon Diakon, VII, 6.

${ }^{13}$ M.J. Leszka, Dlaczego Bizantyńczycy przegrali bitwę pod Anchialos (917). Wersja Leona Diakona, w: In tempore belli et pacis. Ludzie - miejsca - przedmioty. Księga pamiatkowa dedykowana prof. dr hab. Janowi Szymczakowi w 65-lecie urodzin i 40-lecie pracy nakowo-dydaktycznej, red. T. Grabarczyk, A. Kowalska-Pietrzak, T. Nowak, Warszawa 2011, s. 409-414.

${ }^{14} \mathrm{Na}$ temat uzurpacji Bardasa Sklerosa i Bardasa Fokasa - J-C. Cheynet, Pouvoir et contestations à Byzance (963-1210), Paris 1990, s. 331sqq.

15 The History of Leo the Deacon..., s. 11-13.

${ }^{16}$ Leon Diakon, VII, 7. Cf. dwa najważniejsze obok Leona przekazy bizantyńskie - Theophanes Continuatus, ed. B.G. Niebuhr, rec. I. Bekker, Bonnae 1838, s. 405 (dalej: Kontynuacja Teofanesa); Ioannis Scylitzae Synopsis historiarum, rec. I. Thurn, Berlin 1973, s. 202-204; na temat tych relacji N.P. Blagoev, Kritičen..., 1, s. 47-48 (odnosi się także do przekazu Leona Gramatyka i Jana Zonarasa); J. Bonarek, Romajowie i obcy w Kronice Jana Skylitzesa. Identyfikacja etniczna Bizantyńczyków i ich stosunek do obcych ws świetle Kroniki Jana Skylitzesa, Toruń 2003, s. 65-67.

17 Szerzej na temat ukazywania Symeona w źrodłach bizantyńskich patrz m.in.: P. Angelov, Bălgarija..., s. 182-199; M.J. Leszka, Wizerunek władców pierwszego państwa butgarskiego w bizantyń- 
epitety sugerują, że Leon dostrzegał wojskowe umiejętności bułgarskiego władcy, co nie oznacza, że uznawał je za zalety. Skłonność do wojaczki, a przede wszystkim zuchwałość pchała Symeona do ataków na bizantyńskie ziemie. Leon wspomina o jego niszczących najazdach na Macedonię i Trację. Największym grzechem Symeona było żądanie od Bizantyńczyków tego, aby proklamowali go swoim władcą (autokratorem). To przekraczało wyobraźnię Leona, który określił taką postawę mianem szaleństwa (scytyjskiego obłędu). Co więcej stwierdził, że jest to cecha, która generalnie charakteryzuje Myzów. Powyższa charakterystyka Symeona i jego działań realizowanych wobec Bizantyńczyków prowadzić miała czytelnika do konkluzji, że ci ostatni mieli pełne prawo do tego, by podjąć działania, które powstrzymałyby wrogie cesarstwu działania Symeona. W świadomości Bizantyńczyków wojna była złem, którego za wszelką cenę trzeba unikać ${ }^{18}$. Uznawali jednak, że są sytuacje, gdy działania wojenne trzeba podjąć. Bez wątpienia taki krok należy przedsięwziąć jako odpowiedź na czyjąś agresję. Usprawiedliwione jest wkroczenie na tereny przeciwnika, o ile on uczynił to wcześniej w stosunku do bizantyńskiego terytorium ${ }^{19}$. Działania wojenne trzeba także podjąć, jeśli wróg zagraża bizantyńskiej suwerenności i nie zadowala się proponowanymi ustępstwami. Bizantyńczycy usprawiedliwiali wojnę obronną, jak i działania o charakterze prewencyjnym ${ }^{20}$.

Działania Symeona jak najbardziej kwalifikowały się do tego, by wypowiedzieć mu wojnę. Nie dość, że najeżdżał bizantyńskie terytorium, to jeszcze żądał dla siebie tytułu, który przysługiwał jedynie cesarzowi sprawującemu władzę w Konstantynopolu. Nie od rzeczy będzie przypomnieć, że Bizantyńczycy wkraczając na ziemie bułgarskie, działali na terenach które, jak pisał Leon Diakon, kiedyś do nich należały. To także mogło neutralizować ewentualny dyskomfort, będący efektem podjęcia działań wojennych.

Romajowie zostali postawieni przez Symeona w sytuacji bez wyjścia. Musieli bronić swojego terytorium i swojej suwerenności, a przy okazji ukarać zuchwalstwo i butę Symeona. Postawa bułgarskiego władcy była tym bardziej godna ukarania, że prowadził on wrogie działania przeciw cesarstwu w chwili, gdy było ono rządzone przez cesarzową Zoe i Konstantyna VII, jej nieletniego syna. Prowadzenie woj-

skich źródtach pisanych (VIII - pierwsza polowa XII wieku), Łódź 2003, s. 89-123; K. Marinow, In the Shackles of the Evil One: The Portrayal of Tsar Symeon I the Great (893-927) in the Oration „On the Treaty with the Bulgarians”, „Studia Ceranea” 2001, t. 1, s. 157-190; M.J. Leszka, Symeon..., s. 259275; cf. H. Trendafilov, Car i vek. Vremeto na Simeon. Četyri instalacji, Šumen 2017, passim.

${ }^{18}$ Szerzej na ten temat patrz m.in.: S.N. Machalov, Koncepcija mira v političeskoj ideologii Vizantii pervoj poloviny X v.: Nikolaj Mistik i Feodor Dafnopat, Antičnaja Drevnost' i Srednije Veka 27, 1995, s. 19-31; P.M. Strässle, Krieg und Frieden in Byzanz, „Byzantion“ 2004, t. 74, s. 110-129.

${ }^{19}$ Nicholas I Patriarch of Constantinople, Letters, 9, Greek text and English transl. R.J.H. Jenkins, L.G. Westerink. Washington, 1973, s. 62 (dalej: Mikołaj Mistyk, Listy).

20 Świadczy o tym np. list 9 Mikołaja Mistyka do Symeona, w którym biskup przedstawia uzasadnienie zmobilizowania przez Bizantyńczyków znacznych sił i skierowania ich przeciw Bułgarom, ale nie po to, by z nimi walczyć, lecz by zastraszyć ich i wymusić zaniechanie wrogich Bizancjum działań zbrojnych - Mikołaj Mistyk, Listy, 9, s. 58, 60. 
ny przeciw kobiecie i dziecku z pewnością przynosiło, zdaniem Leona Diakona, ujmę Symeonowi i było niegodne władcy ${ }^{21}$.

Po jednoznacznym uczynieniu Symeona odpowiedzialnym za zorganizowanie przez Bizantyńczyków wyprawy wojennej przeciw Bułgarom i naszkicowaniu czarną kreską jego postaci Leon Diakon przechodzi do krótkiego przedstawienia losów zmagań wojennych z uwypukleniem czynów Leona Fokasa, który postawiony został na czele bizantyńskich wojsk lądowych. Historyk określa go mianem mężnego i zwycięskiego. Flotą dowodził drungariusz Roman Lekapen ${ }^{22}$. Leon Fokas po wkroczeniu do Bułgarii zaatakował wojska bułgarskie i zadał im wielkie straty, zmuszając do odwrotu. Symeon, zdaniem Leona Diakona, nie potrafił zorganizować skutecznego oporu, nie wiedział jak powstrzymać śmiałego i niepokonanego wodza Bizantyńczyków, i praktycznie pogodził się z klęską. Gdy wyglądało na to, iż ostateczne zwycięstwo Leona jest tylko kwestią czasu doszło do wydarzenia, które diametralnie zmieniło losy bitwy. Oto bowiem bizantyński wódz otrzymał wiadomość, że Roman, dowódca floty zamiast go wspierać odpłynął do Konstantynopola z zamysłem zdobycia cesarskiej władzy. Ta straszna wieść, jak określa ją dziejopis, wstrząsnęła Leonem Fokasem, który złamał szyk, odwrócił się plecami do Bułgarów i czym prędzej wyruszył do Konstantynopola. Miał bowiem nadzieję, że uda mu się dotrzeć do stolicy przed Romanem i samemu zdobyć cesarski tron. W chwili, kiedy Symeon zobaczył odwrót Bizantyńczyków początkowo sądził, że chcą oni wciągnąć jego wojska w pułapkę. Po chwili doszedł jednak do wniosku, że nie ma takiego niebezpieczeństwa, ruszył więc ze swoimi wojami w pogoń, zadając Bizantyńczykom wielkie straty. Intencją Leona Diakona było, jak sądzę, także w tym epizodzie w złym świetle ukazać Symeona. Kunktator, który nie potrafił właściwie i szybko ocenić sytuacji. Mimo to, że Bizantyńczycy uciekali w nieładzie, nie wydał natychmiastowego rozkazu o pogoni ${ }^{23}$. Gdy po namyśle zdecydował się ścigać Romajów, to, co prawda zwyciężył, ale okazał się człowiekiem okrutnym, bezlitośnie bowiem mordował bizantyńskich żołnierzy. Krwiożerczy Bułgar!. Diakon podkreśla, że jeszcze dziś, kilkadziesiąt lat po tym wydarzeniu, można zobaczyć stosy kości, w miejscu, gdzie pobite zostało wojsko Romajów. Trzeba oddać Leonowi Diakonowi sprawiedliwość, że nie wziął w obronę bizantyńskich żołnierzy, bowiem nazwał ich ucieczkę mianem haniebnej.

${ }^{21}$ To zarzucał Symeonowi już Mikołaj Mistyk - M.J. Leszka, Obraz wojny w Listach Mikołaja Mistyka do Symeona, władcy butgarskiego, „Slavia Antiqua” 2006, t. 47, s. 10, przyp. 7. Argument o niewłaściwości prowadzenia wojny przeciwko państwu bizantyńskiemu rządzonemu przez kobietę pojawia się od czasu do czasu w źródłach bizantyńskich. Cf. list cesarzowej Zofii, żony Justyna II do władcy perskiego (The Ecclesiastical History of Evagrius with the Scholia, V, 12, ed. J. Bidez, L. Parmentier, Amsterdam 1964) czy postawę cesarzowej Teodory, matki Michała III w obliczu agresywnych poczynać bułgarskiego władcy (Kontynuacja Teofanesa, IV, 13, s. 162).

${ }^{22}$ Roman Lekapen, z pochodzenia Armeńczyk. W czasie, kiedy rozgrywała się bitwa pod Anchialos był dowódcą floty, wcześniej był m.in. strategiem Samos. Na jego temat - S. Runciman, The Emperor Romanus Lecapenus and his Reign. A Study of Tenth-Century Byzantium, Cambridge 1969.

${ }^{23}$ Dla współczesnego czytelnika Leona Diakona taka postawa Symeona świadczyć raczej może o jego doświadczeniu i rozwadze. 
Trzeba wyraźnie podkreślić, że bizantyński historyk w swojej narracji odebrał Symeonowi zwycięstwo. Bułgarski władca zwyciężył, ale nie była to jego zasługa. To Bizantyńczycy podali mu je „na tacy”. Gdyby nie rozłam wśród nich, to oni byliby stroną zwycięską, o czym świadczy pierwsza faza zmagań, kiedy to Symeon nie umiał poradzić sobie z wojskami Leona Fokasa ${ }^{24}$.

Na zakończenie tego passusu historyk powraca do losów Leona Fokasa, któremu nie udało się uprzedzić Romana. To ten ostatni opanował cesarski pałac i został ogłoszony basileopatorem. Leon Fokas przeprawił się do Azji, gdzie rozpoczął bunt przyczyniając wiele kłopotów Romanowi i czyniąc wiele szkód państwu. Ostatecznie został jednak pokonany i bezlitośnie oślepiony.

Symeon w przekazie Leona Diakona to postać jednoznacznie negatywna. Butny barbarzyńca, który ośmielił się nie tylko najeżdżać na bizantyńskie terytorium, ale i żądać, by Romajowie proklamowali go swoim władcą. Parafrazując słowa włożone przez samego Leona Diakona w usta Nicefora Fokasa można by rzec, że to niewolnik, który śmiał wystąpić przeciw Romajom, swoim panom. Nawet jego zwycięstwo pod Anchialos nie było owocem jego wojskowego kunsztu, a skutkiem rozdarcia w obozie bizantyńskim. Trzeba wyraźnie podkreślić, że to nie on był bohaterem analizowanego w artykule fragmentu dzieła Leona Diakona - tym był Leon Fokas. Bułgarski władca stał się w rękach bizantyńskiego autora jedynie wygodnym narzędziem do realizacji celu ukazania dość banalnej prawdy, że niezgoda we własnym obozie i żądza władzy prowadzą do nieszczęść tak w wymiarze osobistym, jak i całego państwa.

Leon Diakon, z perspektywy swojej wiedzy o dalszych losach panowania Symeona i doświadczeń, dotyczących relacji bułgarsko-bizantyńskich końca $\mathrm{X}$ wieku, pozbawiony był jakichkolwiek złudzeń, co do charakteru i intencji tego konkretnego bułgarskiego władcy, jak i Bułgarów w ogóle. Bułgarzy, mimo wspólnej religii, to niebezpieczni wrogowie, których trzeba ujarzmić i poddać władzy Romajów.

\section{BIBLIOGRAFIA}

\section{Źródla:}

Ioannis Scylitzae Synopsis historiarum, rec. I. Thurn, Berlin 1973.

Leonis Diaconi Caloensis Historiae, rec. C.B. Hase, Bonnae 1828.

Nicholas I Patriarch of Constantinople. Letters, Greek text and English transl. R.J.H. Jenkins, L.G. Westerink. Washington, 1973.

${ }^{24}$ Szerzej na temat uzasadnienia przez Leona Diakona klęski pod Anchialos - M.J. Leszka, Dlaczego.... 
Testimonia najdawniejszych dziejów Słowian, seria grecka, zeszyt 5: Pisarze z X wieku, przekł., oprac. A. Brzóstkowska, Warszawa 2009.

The Ecclesiastical History of Evagrius with the Scholia, ed. J. Bidez, L. Parmentier, Amsterdam 1964.

The History of Leo the Deacon. Byzantine Military Expansion in the Tenth Century, introd., transl., annot.

A-M. Talbot, D. F. Sulivan, with assistance G. T. Dennis, S. McGrath, Washington 2006.

Theophanes Continuatus, ed. B.G. Niebuhr, rec. I. Bekker, Bonnae 1838.

\section{Opracowania:}

Angelov D., Kašev S., Čolpanov B., Bălgarska voenna istorija ot antičnostta do vtorata četvărt na Xv., Sofia 1983.

Angelov P., Bălgarija i bălgarite v predstavite na vizantijcite (VII-XIV vek), Sofia 1999.

Bălgarskijat zlaten vek. Sbornik w čest na car Simeon Veliki (893-927), red. V. Gjuzelev, I.G. Iliev, K. Nenov, Plovdiv 2015.

Blagoev N.P., Kritičen pogled vărhu izvestijata na Lăv Djakon za bălgarite, „Makedonski Pregled” 1930, t. 6 , nr 1, s. 25-48; 2, s. 23-40.

Bonarek J., Romajowie i obcy w Kronice Jana Skylitzesa. Identyfikacja etniczna Bizantyńczyków i ich stosunek do obcych w świetle Kroniki Jana Skylitzesa, Toruń 2003.

Božilov I., Car Simeon Veliki (893-927); zlatnijat vek na Srednovekovna Bălgarija, Sofia 1983.

Božilov I., Gjuzelev V., Istorija na srednovekovna Bălgarija VII-XIV vek, Sofia 1999.

Brzozowska Z.A, Leszka, M.J., Marinow K., Piotr I Święty, car bułgarski (ok. 912-969), Maria Lekapena, caryca butgarska (ok. 912-?963), Kraków 2018.

Cheynet J.-C., Les Phocas, w: Le Traité sur la guérilla (De velitatione) de l'empereur Nicephore Phocas (963-969), ed. G. Dagron, H. Mihaescu, Paris 1986.

Cheynet J-C., Pouvoir et contestations à Byzance (963-1210), Paris 1990.

Durić I., Porodica Foca, “Zbornik Radova Vizantološkog Instituta” 1976, t. 7, s. 240-246.

Holmes C., Basil II and Governance of Empire (976-1025), Oxford 2005.

Holmes C., Political Elites in the Reign of Basil II, w: Byzantium in the Year 1000, ed. P. Magdalino, Leiden 2003, s.

Ivanov S.A., Polemičeskaja napravlennost “Istorii” Lva Diakona, „Vizantijskij Vremennik” 1982, t. 43, s. 74-80.

Jurewicz O., Historia literatury bizantyńskiej, Wrocław 1982.

Karpozilos A., Bydzantinoi istorikoi kai chronografoi 8-10os aiones, Athenai 2002, t. 2.

Kazhdan A., History of Byzantine Literature (850-1000), ed. Ch. Angelidi, Athens 2006, s. 278-286.

Leszka M.J., Dlaczego Bizantyńczycy przegrali bitwę pod Anchialos (917). Wersja Leona Diakona, w: In tempore belli et pacis. Ludzie - miejsca - przedmioty. Ksiega pamiatkowa dedykowana prof. dr hab. Janowi Szymczakowi w 65-lecie urodzin i 40-lecie pracy nakowo-dydaktycznej, red. T. Grabarczyk, A. Kowalska-Pietrzak, T. Nowak, Warszawa 2011, s. 409-414.

Leszka M.J., Obraz wojny w Listach Mikołaja Mistyka do Symeona, władcy bułgarskiego, „Slavia Antiqua" 2006, t. 47, 2006, s. 9-16.

Leszka M.J., Symeon I Wielki a Bizancjum. Z dziejów stosunków bułgarsko-bizantyńskich w latach 893 927, Łódź 2013.

Leszka M.J., Wizerunek władców pierwszego państwa bułgarskiego w bizantyńskich źródłach pisanych (VIII - pierwsza połowa XII wieku), Łódź 2003.

Ljubarskij J.N. Zamečanija ob obrazach i chudożestvennoj prirode „Istorii” Lva Diakona, w: idem, Vizantijskije istoriki i pisateli (sbornik statiej), Sankt-Peterburg 1999, s. 149-160.

Machalov S.N., Koncepcija mira v političeskoj ideologii Vizantii pervoj poloviny X v.: Nikolaj Mistik i Feodor Dafnopat, „Antičnaja Drevnost' i Srednije Veka” 1995, t. 27, s. 19-31.

Marinow K., In the Shackles of the Evil One: The Portrayal of Tsar Symeon I the Great (893-927) in the Oration ,On the Treaty with the Bulgarians", "Studia Ceranea” 2011, t. 1, s. 157-190.

Neville L., Guide to Byzantine Writing, Cambridge 2018.

Panagiotakes N., Leon ho Diakonos. A: Ta Bibliografika, B: Cheirografa kai eksdosis, Athenai 1965. 
Panov M.P., The Blinded State. Historiographic Debates about Samuel Cometopoulos and His State $\left(10^{\text {th }}-11^{\text {th }}\right)$, Leiden-Boston 2019.

Pirivatrić S., Samuilova država. Obim i karakter, Beograd 1997.

Runciman S., The Emperor Romanus Lecapenus and his Reign. A Study of Tenth-Century Byzantium, Cambridge 1969.

Simeonova Bălgarija v istorijata na evropejskija jugoiztok: 1100 godini ot bitkata pri Aheloj, red. A. Nikolov, N Kănev, Sofija 2018, t. 1-2,

Sjuzjumov M.J., Lev Diakon i jego vremia, w: Lev Diakon, Istorija, perev. M.M. Kopylenko, kommentarii M.J. Sjuzjumov. S.A. Ivanov, Moskva 1988, s. 137-165.

Strässle P.M., Krieg und Frieden in Byzanz, „Byzantion“ 2004, t. 74, s. 110-129.

Strässle P.M., Krieg und Kriegführung in Byzanz. Die Kriege Kaiser Basileios' II. gegen die Bulgarien 976-1019, Köln-Weimar-Wien 2006.

Tomov T., Ključ 1014, Sofija 2014.

Trendafilov H., Car i vek. Vremeto na Simeon. Četyri instalacji, Šumen 2017.

Zlatarski V., Istorija na Bălgarskata dăržava prez srednite vekove, Sofia 1927, t. I.2. 
